\title{
Marketing Strategy Analysis to Increase Occupancy Room Based on Travel Agent Online Market Segment (Case Study in Whiz Zprime Hotel Pajajaran Bogor)
}

\author{
Ali Maddinsyah ${ }^{1}$, Udin Ahidin ${ }^{2}$, Yayan Sudaryana ${ }^{3}$, \\ Sugiyanto Sugiyanto $^{4}$, Yandri Yandri ${ }^{5}$ \\ Department of Management, Universitas Pamulang, Indonesia \\ alimaddinsyah@unpam.ac.id
}

\begin{abstract}
Since the hotel operates from November 2015 until July 2018 the occupancy room level has always changed inconsistently. The purpose of this study is to analyze the current marketing strategy and to find out more appropriate strategies in increasing occupancy rooms based on the online travel agent market segment at Whiz Prime Hotel Pajajaran Bogor. The analysis was carried out through IFE matrix analysis, EFE matrix, IE matrix, SWOT matrix, and QSPM matrix. The results showed that the condition of the marketing strategy with IE matrix analysis was in a position of growth and development with the meeting point value of IFE 335 and EFE 376. In this position the strategy that must be carried out is market penetration, market development, product development, forward integration, and backward integration. Based on SWOT matrix analysis the strategy that must be done is to display complete information, add hotel facilities, improve product and service quality, and improve the quality of human resources. The results of the analysis using the QSPM matrix show that the most appropriate strategy carried out by Whiz Prime Hotel Pajajaran Bogor is to improve product and service quality.
\end{abstract}

Keywords: Marketing Strategy, IFE matrix, EFE matrix, IE matrix, SWOT, QSPM

\section{Introduction}

Tourism business in Indonesia is quite potential because Indonesia has a lot of potential natural beauty, diversity and cultural uniqueness and so on. This also affected the development of the hotel and tourism business in Indonesia which increased significantly. Hotel is one of the commercially managed accommodation, which is provided for everyone to obtain services, lodging and food and beverages (based on Minister of Transportation Decree No. PM 16

/ PW 301 / PHB 77 dated December 22, 1977 in chapter Article 7 paragraph a)The hospitality industry is a service industry that combines products and services. The design of buildings, interior and exterior of hotel rooms and restaurants, the atmosphere created in hotel rooms, the food and drinks sold along with all the available facilities are examples of products sold. While the services sold are hospitality and skills in serving their customers.

Along with tight competition in the hotel business, especially in the Bogor area so that hoteliers need to carry out strategies to increase their hotel occupancy rooms along with the emergence of new hotels in the Bogor area, especially on the main streets of Pajajaran Bogor such as the Zest Hotel, the Arch Hotel, the Amaris Hotel, and the Pangrango hotel which are competitors. Therefore, the competitor's hotel marketing team competes with strategies and innovations to improve the hotel occupancy room. The same thing was done by the Markeing 
Whiz Prime Hotel Pajajaran Bogor team, always doing the right strategies and innovations to increase the occupancy room.

Many factors affect the increase in occupany room at Whiz Prime Hotel Pajajaran Bogor. One way is to use technology. By utilizing internet technology will provide ease of activity. These advantages make all processes faster so consumers can book hotels more practically and efficiently. It is proven that many guests stay at Whiz Prime Hotel Pajajaran Bogor, which is dominated by guests of online travel agents. Based on the background described above, the focus of this study is as follows:

a) This study analyzes marketing strategies based on market segments focused on the online travel agent market in increasing occupancy rooms in Whiz Prime Hotel Pajajaran Bogor.

b) This study focuses on analyzing, in order to establish a more appropriate strategy in increasing occupancy rooms in Whiz Prime Hotel Pajajaran Bogor.

Research Purposes:

a) To analyze the marketing strategy of Whiz Prime Hotel Pajajaran Bogor, in increasing occupancy rooms based on the market segment of the online travel agent $t$ at this time.

b) To analyze more right marketing strategies determined at Whiz Prime Hotel Pajajaran Bogor, in increasing occupancy rooms based on the online travel agent market segment.

\section{Theory}

According Assauri (2008: 168) defines that marketing strategy is a set of goals, policies, and rules that give direction to the company's marketing efforts from time to time, at each level and reference and allocation, especially as a response to the company in dealing with the changing environment and competition. Therefore the marketing strategy must be set based on an environmental and internal analysis of the company through an analysis of the company's strategic strengths and weaknesses, as well as an analysis of the opportunities and threats faced by the company from its environment. While Swastha and Handoko (2012: 119) explain that a marketing strategy is several specific actions, but rather a statement that shows the main marketing efforts for achieving the goal. Furthermore, marketing strategy, according to Alma (2012: 199), is a decision pattern in a company that determines and expresses the goals, intentions, or objectives that produce the main policy and plans for achieving the goals and details the scope of the business that the company will pursue. Hasan (2013: 436) argues that a good marketing strategy must be built by a strong business understanding, combined with an understanding of the needs and desires of customers, competitors and capabilities, and core business including with suppliers and distributors.

Marketing strategy, according to Tjiptono (2013: 6), means that a marketing strategy is a fundamental tool and planning to achieve the goals of a company by developing sustainable competitive advantage through the markets entered and marketing programs used to serve the target market. Based on the understanding put forward by the experts above, the marketing strategy is a comprehensive, integrated, and unified plan in the field of marketing that provides a mix of activities to achieve the company's goals. In other words, a marketing strategy is a set of goals, objectives, policies, and rules that give direction to the company's marketing efforts from time to time at each level and its references and allocations, especially in dealing with the environment and ever-changing competition conditions. 


\section{Metodology}

This research was conducted in Whiz Prime Hotel Pajajaran Bogor, which is located at Jalan Cikuray No. 47 Pajajaran, Kelurahan Babakan, Kecamatan Bogor Tengah Kota Bogor, West Java Postal Code 16128 Telephone 0251- 7560088- Fax 0251-7560077. Limitation of the problem of this study is only to discuss the company's internal and external factors obtained through interviews with the management of Whiz Prime Hotel Pajajaran Bogor which includes:

a) The company's internal environment includes management (planning, organizing, actuating, controlling), marketing (product, price, place, promotion, process, person, physical evidence, productivity, and quality) research and development and information systems.

b) The company's external environment includes the microenvironment (suppliers, customers, competitors), the industrial environment (the threat of substitute products, competition between companies, the threat of new entrants), and the macro environment (demographic, economic, social, political, and technological).

The research procedure was carried out as follows:

a) Preliminary Survey,is used to determine the condition of the company, so that writers can find a clear conception of Whiz Prime Hotel Pajajaran Bogor.

b) The problem was identified through a direct interview with management of Whiz Prime Hotel Pajajaran Bogor

c) The interviews included the Sales and Marketing Department of Whiz Prime Hotel Pajajaran Bogor and guests from online travel agents. Data obtained from the results of interviews are used as primary data. The primary data is data obtained from informants through direct interviews conducted by researchers at the research location.

d) Literature Study, Literature studies are used to find information and theoretical basis that supports research. Literature studies come from books, journals, magazines and others.

e) Identification of Research Variables, The identification of research variables consists of external environmental variables and internal variables of the company. The identification of internal factors is obtained through interviews with company management. Internal company variables consist of management (planning, organizing, actuating, controlling), marketing (product, price, place, promotion, process, person, physical evidence, productivity, and quality) research and development and information systems. External variables consist of the micro environment (suppliers, customers, competitors), the industrial environment (substitution product threats, competition between companies, the threat of new entrants), and the macro environment (demographic, economic, social, political, and technological).

f) Respondents were selected purposively consisting of three people from internal, including Sales Manager and Reservation from Whiz Prime Hotel Pajajaran Bogor. Also, two respondents from external, that are guests of the Whiz Prime Hotel Pajajaran Bogor, who made hotel reservations through an online travel agent and were willing to become respondents.

g) The validity test in this study uses face validity. Face validity is a decision whether the instrument in question measures the desired concept. Decisions about face validity are also subjective and usually include a process in which experts with construction and field test fields interest in assessing instruments to see if in their opinion instruments 
measure what it means to measure. Face validity refers to people's opinions about the credibility of the test. Irrelevant questions will make test-takers doubt the validity of the test and produce less credible answers (Browning, 2007).

h) Data Analysis, In developing marketing strategies, it uses the SWOT method and Quantitative Strategic Planning Matrix (QSPM).

\section{Results And Discussion}

Whiz Prime Hotel Pajajaran Bogor is a three-star hotel under the Intiwhiz International Management and a subsidiary of PT. Intiland Development Tbk. Whiz Prime Hotel Pajajaran Bogor began operations on November 16, 2015. Whiz Prime Hotel Pajajaran Bogor has 153 rooms and 5 meeting rooms. Access to get to the hotel place is very easy because the Whiz Prime Hotel Pajajaran Bogor is located in the heart of Bogor City on Cikuray street No.34 Pajajaran, Bogor, West Java.

\subsection{Internal Environmental Analysis}

The internal environment discusses the strengths and weaknesses of the company. Internal factors used in research based on the state of the company consist of management, marketing, research and development, and information systems. The strength and weakness variables of each factor are shown in Table 1.

\subsection{External Environmental Analysis}

The external environment leads to opportunities and threats. Opportunities can build organizational activities while threats hamper organizational movement. External factors discussed in this study are the micro environment, industrial environment and macro environment. The opportunity and threat variables for each factor can be seen in Table2.

\subsection{IFE (Internal Factor Evaluation) Matrix}

Internal environment analysis is carried out through identification of company internal factors to determine the strengths and weaknesses of the company. Once identified, weighting and rating of each variable are carried out. Based on the results of weighting and rating using the IFE matrix it can be seen that the total score of the IFE matrix is 3.181. The table of IFE matrix results can be seen in Table 3. The total score shows a strong position.

Table 1. Identify strengths and weaknesses

\begin{tabular}{|c|c|}
\hline Internal Factor Strength & Weakness \\
\hline $\begin{array}{l}\text { 1. Strategic location by displaying the "One Stop Services } \\
\text { Concept }\end{array}$ & $\begin{array}{l}\text { 1. The capacity of the parking area is less } \\
\text { extensive }\end{array}$ \\
\hline 2. Very competitive prices & 2. Limited human resources (labor) \\
\hline 3. The hotel facilities are quite complete & 3. The size of the hotel room is less extensive \\
\hline $\begin{array}{l}\text { 4. The services of all Whiz Prime Hotel Pajajaran Bogor staff } \\
\text { are welcoming and friendly }\end{array}$ & $\begin{array}{l}\text { 4. Bathroom layout in the room that is } \\
\text { designed separately between the toilet and } \\
\text { the shower }\end{array}$ \\
\hline $\begin{array}{l}\text { 6. Collaborating with several online travel agents } \\
\text { (traveloka, booking.com, pegi-pegi, expedia and Tiket.com) }\end{array}$ & 5. Not all hotel rooms have closet facilities \\
\hline
\end{tabular}


Table 2. Identification of opportunity and threat factors

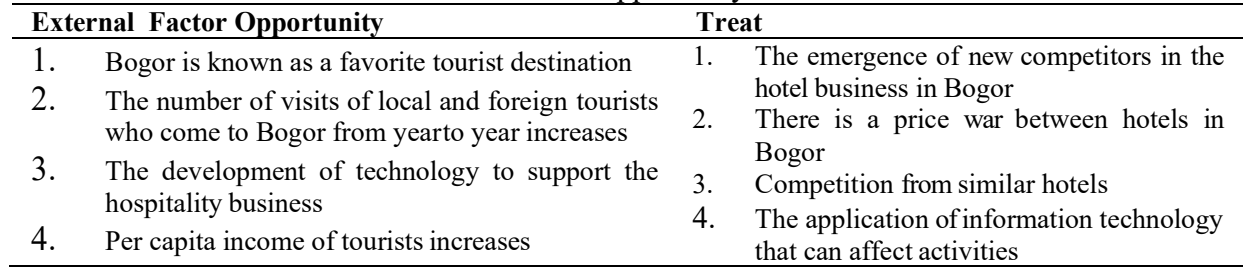

Table 3. IFE Matrix Results

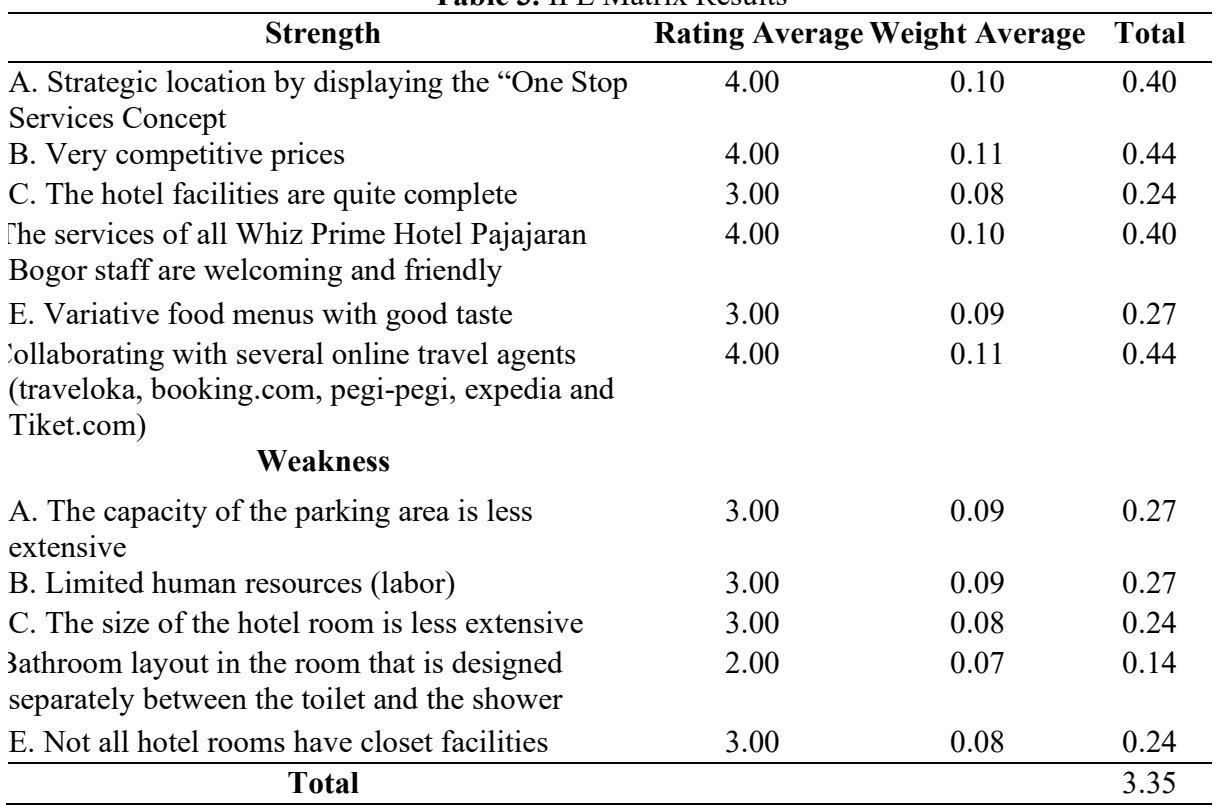

Table 4. EFE Matrix Results

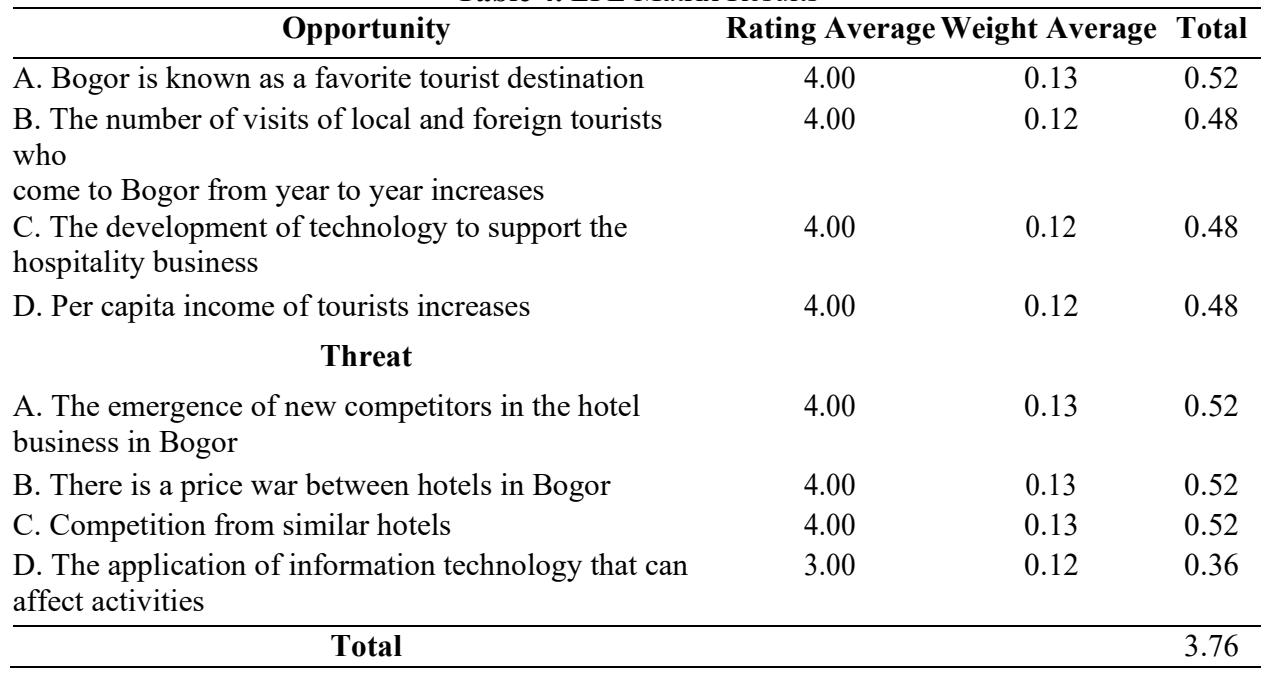


Table 5. QSPM Results

\begin{tabular}{clc}
\hline No. & Strategic Alternative & Total TAS \\
\hline 1 & Display complete information & 4.75 \\
2 & Adding hotel facilities & 4.25 \\
3 & Improve product and service quality & 5.11 \\
4 & Improve the quality of resources & 3.76 \\
\hline
\end{tabular}

\subsection{EFE Matrix (External Factor Evaluation)}

EFE matrix analysis is the result of identifying external factors in the form of opportunities and threats that affect the Whiz Prime Hotel Pajajaran Bogor. The result of multiplication between weighting averages and rating assessment will produce a total score. The main opportunity for this company based on the highest score is that Bogor is known as the second favorite tourist destination in West Java after Bandung. Based on the results of weighting and rating using the IFE matrix it can be seen that the total score of the IFE matrix is 3.76. The table of EFE matrix results can be seen in Table 4.

\subsection{IE Matrix}

Based on the results of the IFE matrix and EFE matrix, it can be arranged later in the IE matrix. The average value of IFE was 3.35 and the average EFE was 3.76. The average value of IFE and EFE is obtained from the sum of the scores on each factor, where the score is obtained from the multiplication between the average rating and the average weight for each factor. Because in the IE matrix the scale used is 100 to 400 , the value of the IFE and EFE matrices are both made into hundreds, namely the value of the IFE matrix being 335 and the EFE matrix being 376 , this value indicates the quadrant position I, which indicates the strategy needed for the company now is Grow and Build. In this quadrant the strategy that must be carried out is toshow that the company needs a strategy to grow better and can develop the company for the better. The strategies that can be applied by companies today are Market Penetration, Market Development, Product Development, Forward Integration Strategy, Backward Integration, and Horizontal Integration. IE matrix can be seen in Figure 1. below:

$$
300 \quad 400
$$

100

\begin{tabular}{|c|c|c|}
\hline Grow and Build & Grow and Build & $\begin{array}{c}\text { Survve and } \\
\text { Guard }\end{array}$ \\
\hline Grow and Build & $\begin{array}{c}\text { Survive and } \\
\text { Guard }\end{array}$ & $\begin{array}{c}\text { Take off or } \\
\text { Divest }\end{array}$ \\
\hline Grow and Build & $\begin{array}{c}\text { Take off or } \\
\text { Divest }\end{array}$ & $\begin{array}{c}\text { Take off or } \\
\text { Divest }\end{array}$ \\
\hline
\end{tabular}

Fig.1. Averaged Value of IFE

\section{a) Market Penetration}

Market penetration is looking for market segmentation that can increase demand for 
products or services through greater marketing. To penetrate the market, there are several things done by Whiz Prime Hotel Pajajaran Bogor. The marketing team makes regular expenses to provide attractive offers for guests who are loyal to Whiz Prime Hotel Pajajaran Bogor. This will have a positive impact on hotel occupancy. At present, several promotional programs at Whiz Prime Hotel Pajajaran Bogor include:

1) Long Stay Package. The guest only pays Rp. 425,000 ,- with a minimum requirement to stay at Whiz Prime Hotel Pajajaran Bogor for seven days. In this package, guests will get the facilities of one type of standard king room including breakfast for one person and free laundry services every day (five sets of clothes per day). Guests will also get an additional $5 \%$ discount for room service purchases and an additional 5\% discount for using laundry services if they exceed the specified laundry package.

2) Smash Rate Package. The guest only pays Rp. 375,000, - and will get one standard type king room facilities, no breakfast, and get a 5\% discount for room service purchases. The promo is valid only on Sundays and Monday (not included in high seasons) with walk-in reservations.

3) Sumo Rate Package is a guest who stays at Whiz Prime Hotel Pajajaran Bogor will get a standard one- room type king room, breakfast for one person, and a 5\% discount for room service. The promo is valid only on Sundays and Mondays (not included in high seasions) with a walk-in reservation.

\section{b) Market Development}

Market development is introducing new products or services into new geographical areas. In other words, doing market development when the market is saturated. Some strategies carried out by Whiz Prime Hotel Pajajaran Bogor work with several travel agents in Jakarta such as Mg Holiday, Raja Kamar, Anta Vaya, in Surabaya such as Haryono Tour and Travel, Kaha and in Bali such as Kusuma Holidays, Panorama Destination Bali. The aim is to make the Whiz Prime Hotel Pajajaran Bogor better known. It is hoped that residents outside of Bogor can order travel agent accommodation services when traveling to Bogor.

\section{c) Product Development}

Product development is to increase sales by increasing current products or services or developing new ones. Whiz Prime Hotel Pajajaran Bogor launched the Whiz Mate Loyalty program which is a program designed to reward guests who stay at the core hospitality management hotel network (Whiz Capsule, Whiz Hotel, Whiz Prime, Grand Whiz and Swift Inn) with various benefits including the best price guarantee, Prize points and special promos Forward Integration Forward Integration is a business ownership effort that can help product distribution. Whiz Prime Hotel Pajajaran Bogor, through the CEO of Whiz Prime Hotel Pajajaran Bogor, already has a subsidiary that manufactures health beds or in the market known as orthopedic mattresses. These mattress products are used in all Intiwhiz International hotel chains, such as Whiz Hotel, Whiz Prime, and Grand Whiz.

\section{d) Backward Integration}

Backward Integration is seeking ownership or increasing control over the company's suppliers. This has been done by Whiz Prime Hotel Pajajaran Bogor. Since opening on November 16, 2015, all consumption for hotel guests is supported by catering vendor. However, since the middle of 2016, all food products are supplied by themselves. To support 
this, Whiz Prime Hotel Pajajran Bogor made several changes such as the construction of a kitchen area and the recruitment of employees for kitchen operations.

\section{e) Horizontal Integration}

Horizontal Integration is seeking ownership or increasing control over competitors. At present Whiz Prime Hotel has no strategy for Horizontal integration

\subsection{SWOT Matrix}

The SWOT matrix produces several alternative strategies obtained from internal and external variables according to the company's position in the IE matrix, Grow and Build. The alternative strategies are as follows:

\section{a) SO Strategy}

1) Showing complete information about hotel properties in an online travel agent.

2) Increase promotion through online travel agent media so that more tourists check-in through online travel agents.

3) Establish good cooperation between the hotel and online travel agents so that the mutual benefit between the hotel and online travel agents.

4) The drop in knowledge about each travel agent's online website.

5) Improve management and collaboration capabilities for the company's goals.

\section{b) WO Strategy}

1) Provides free valet facilities to guests who stay overnight.

2) Prepare additional parking spaces when the hotel parking area is full.

3) Maximizing the existing workforce and adding casual employees in hight season.

4) Adding hotel facilities that are not yet available in the hotel according to the hotel guest comment.

5) Provide delivery order services for consumers.

\section{c) ST Strategy}

1. Improve product and service quality so that guests feel comfortable and want to return to the hotel.

2. Always monitor the prices of competitors in determining the selling price of rooms in an online travel agent.

3. Provide accurate information and not to exaggerate or reduce from the facts in the field.

4. Collaborate with the IT department so that there is no human error in Wibeste and routine checks from IT system vendors

\section{d) WT Strategy}

1) Improving the quality of human resources (Employees) such as training in each hotel department.

2) There is a cheaper price between booking in the hotels compared to booking through online travel agents. 


\subsection{Quantitative Strategy Planning Matrix (QSPM)}

The final stage of strategy analysis is the selection of an appropriate and workable strategy. The selection of suitable strategies is to use QSPM analysis tools. Alternative strategies are obtained from the SWOT matrix where the matrix produces several alternative strategies through internal and external factors of the company. From the calculation of the QSPM matrix in table 5 , the total score of strategy 1 is 4.75 strategy 2 is 4.28 strategy 3 is 5.11 strategy 4 is 3.76. Based on the QSPM matrix analysis the most appropriate strategy carried out by Whiz Prime Hotel Pajajaran Bogor in increasing the occupancy rate significantly based on the market segment of Whiz Prime Hotel Pajajaran Bogor is strategy 3. The field for strategy 1,2 and 4 has been carried out by Whiz management Prime Hotel Pajajaran Bogor. Product quality improvement focused on the quality of the appearance of hotel facilities and infrastructure. Meanwhile, to improve the quality of service to guests can be done with fast and responsive service, listen to complaints of hotel guests, maintain patience, politeness, admit mistakes, be personal, provide a place for feedback, establish 24-hour support, and offer special VIP services.

\section{Conclusion}

Based on the results of IE analysis, the condition of the marketing strategy of Whiz Prime. Hotel Pajajaran Bogor is at the meeting point of IFE 335 and EFE 376 which means being in guardant of growing and building. In this condition, the hotel have to do the market penetration by organizing promotional programs. promotions carried out by Whiz Prime Hotel Pajajaran Bogor can be such as long stay packages, smah rate packages, Sumo rate packages, and entertain for loyal guests. The aim of this promotions is for attracting the guests. For floating the market can do by cooperation online travel agents in the outside city of Bogor. Product Development assisted by the hotel management is the Whiz Mate Loyalty program. It which is a program designed to reward guests staying at hotels of whiz Prime such as the guaranteed price, points and special promos. The forward integration is to use its own products such as beds and have been used throughout the intiwhiz management network including Whiz Prime Hotel Pajajaran Bogor. Backward integration conducted by Whiz Prime Hotel Pajajaran Bogor, changes in terms of serving food that previously used a catering vendor from 2017 and slaso increase the meeting room to be greater capacity. Base on the results of the SWOT matrix analysis obtained alternative strategies is more appropriate for Whiz Prime Hotel Pajajaran Bogor, such as:

a) Showing the complete information about Whiz Prime Hotel properties in an online travel agent.

b) Adding hotel facilities that are not available according to the guest comments.

c) Improving the product and service quality.

d) Increasing the quality of resources (hotel employees).

e) Based on the results of the QSPM matrix analyst, the most appropriate strategy of Whiz Prime Hotel Pajajaran Bogor for increasing occupancy rooms based on the online travel agent market segment is improving the quality of products and services so that guests feel comfortable and want to return to the hotel.

The current condition of marketing strategy the Whiz Prime Hotel Pajajaran Bogor is in the conditions of growth and development, so that it is recommended for doing: In market 
penetration it is suggested that there is an attractive promotional package, specifically for guests who make reservations through online travel agents are provided, such as :

a) Stay package includes laundry service at an economis price,

b) Honeymoon packages that are not sold on online travel agents.

c) Additional costs for entertainment and additional services for loyal guests, especially guests who make reservations through an online travel agent.

Market Development, namely introducing new products or services to new areas outside the Bogor and Jakarta regions in collaboration with several travel agents. However, in the future it is recommended to visit several travel agents that are outside the city for the purpose of maintaining good relations with those travel. Product Development Whiz Prime Hotel Pajajaran Bogor by organizing the Whiz Mate Loyalty program, which is a program designed to reward guests staying throughout the intiwhiz hotel. The program must be providing the various benefits such as price guarantees, points, and special promos. Using the collaboration with the team front office, the marketing team must share the information of this product to guests.

Forward integration is a business ownership effort that can help product distribution. At this time for the needs of coffee break still making purchases through a catering vendor. In the future it is suggested that for the needs of the coffee break can be produced by hotel, it will give the benefits such low cost and have the consistent of taste. For the marketing strategy of increasing occupancy rooms in Whiz Prime Hotel Pajajaran Bogor, including. To display images and information about Whiz Prime Hotel Pajajaran Bogor property in several online travels. It must be interesting and providing detail and clear information. is recommended take pictures of property more in several online travel agents. Because of visitors prefer things that are interesting and colorful. Provide and improve facilities that have been commented by customers. To improve the quality of products and services, it is advisable to conduct trainings according to their respective jobs, and invite a team of experts from outside in accordance with their fields. To improve the quality of human resources (hotel employees), it must do a training in each department for knowing more about the products. It is also suggested for the cross training between departments.

\section{References}

[1] Ikhsan, Arfan, Prianthara, Ida Bagus Teddy. 2008. Sistem Akuntansi Perhotelan. Yogyakarta: Graha Ilmu

[2] Nawawi Ahmad. 2015. Partisipasi Masyrakat Dalam Pengelolaan Wisata Pantai Depok di Desa Kretek Parangtritis, Jurnal Nasional Pariwisata Volume 5 Nomer 2: Yogyakarta

[3] Sunyoto Danang. 2013. Teori, Kusioner, dan Analisis Data Sumber Daya Manusia. Jakarta. PT. Buku Seru

[4] Limakrisma Nandan, Parul Togi. 2017. Manajemen Pemasaran (Teori dan Aplikasi Dalam Bisnis Edisi 2 ). Bogor: Mitra wacana Media

[5] David, F.R., 2016, "Manajemen Strategik, Suatu Pendekatan Keunggulan Bersaing”, Edisi Ke 15, Salemba Empat, Jakarta.

[6] Kotler, P. dan Amstrong, G., 2012, "Prinsip-Prinsip Pemasaran", Edisi Ke Dua Belas, Jilid Satu, Erlangga, Jakarta.

[7] Kotler, P. dan Keller, K., 2009, "Manajemen Pemasaran”, Edisi Kedua Belas, PT. Indeks, Jakarta. 
[8] Kotler, P. dan Keller, K.L., 2012, "Manajemen Pemasaran", PT. Macaman Jaya Cemerlang, Jakarta.

[9] Hurriyati, R., 2012, "Bauran Pemasaran Dan Loyalitas Konsumen", CV. Alfabeta, Bandung.

[10] Noor, J., 2012, "Metodologi Penelitian", Kencana Prenada Media Group, Jakarta.

[11] Nugroho, A.A., 2008, "Manajemen Informasi", Graha Cipta, Jakarta.

[12] Riduwan., 2014, "Metode dan Teknik menyusun Tesis", Alfabeta, Bandung.

[13] Robbin, S.P., dan Coulter, M., 2012, "Manajemen", Edisi ke Sepuluh, Erlangga, Jakarta.

[14] Shinta, A., 2011, "Manajemen Pemasaran", Cetakan Pertama, UB Press, Jakarta.

[15] Sugiyono, 2012, "Metode Penelitian Kuantitatif Kualitatif dan R\&D", CV. Alfabeta, Bandung.

[16] Hurriyati, R., 2012, "Bauran Pemasaran Dan Loyalitas Konsumen", CV. Alfabeta, Bandung.

[17] https://www.whizprime.com/bogor/maps.php

[18] https://www.tripadvisor.co.id/Hotel Review-g297706-

d8139702ReviewsWhiz_Prime_Hotel_Pajajaran_Bogor Bogor_West_Java_Java.html

[19] https://www.bps.go.id/linkTableDinamis/view/id/980

[20] https://kotabogor.go.id/index.php/show_post/detail/5721/jumlah-wisatawan-2017- 